\title{
Pristine and Carboxyl-Functionalized Tetraphenylethylene-Based Ladder Networks for Gas Separation and Volatile Organic Vapor Adsorption
}

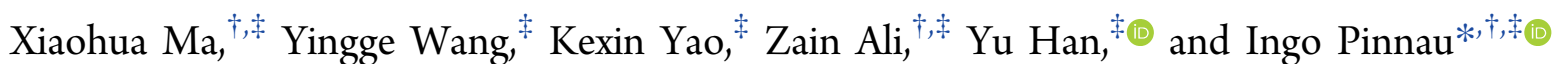

${ }^{\dagger}$ Functional Polymer Membranes Group and ${ }^{\ddagger}$ Advanced Membranes and Porous Materials Center, Division of Physical Sciences and Engineering, King Abdullah University of Science and Technology (KAUST), Thuwal 23955-6900, Saudi Arabia

Supporting Information
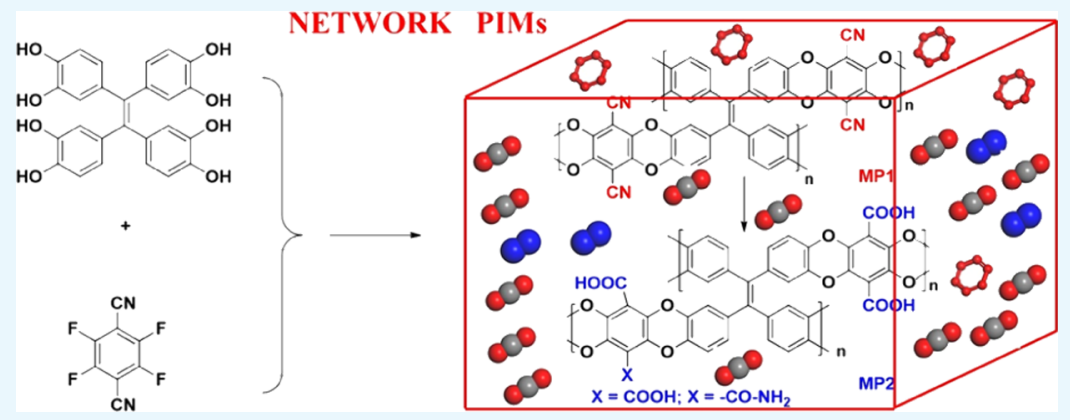

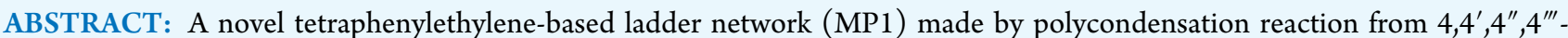
(ethene-1,1,2,2-tetrayl)tetrakis(benzene-1,2-diol) and 2,3,5,6-tetrafluoroterephthalonitrile and its COOH-functionalized analogue (MP2) were synthesized for the first time. Their structures were confirmed by solid-state nuclear magnetic resonance $\left({ }^{13} \mathrm{C}\right.$ cross-polarization magic angle spinning), Fourier transform infrared spectroscopy, and elementary analysis. MP1 exhibited a high Brunauer-Emmett-Teller surface area $\left(1020 \mathrm{~m}^{2} \mathrm{~g}^{-1}\right)$, whereas the COOH-functionalized MP2 showed a much smaller surface area $\left(150 \mathrm{~m}^{2} \mathrm{~g}^{-1}\right)$ but displayed a more uniform pore size distribution. Because of the high density of nitrile groups in the network polymers of intrinsic microporosity (PIMs) and strong interaction with quadrupole $\mathrm{CO}_{2}$ molecules, MP1 exhibited a high $\mathrm{CO}_{2}$ adsorption capacity of $4.2 \mathrm{mmol} \mathrm{g}{ }^{-1}$ at $273 \mathrm{~K}$, combined with an isosteric heat of adsorption $\left(Q_{\mathrm{st}}\right)$ of $29.6 \mathrm{~kJ} \mathrm{~mol}^{-1}$. The COOH-functionalized MP2 showed higher $Q_{\mathrm{st}}$ of $34.2 \mathrm{~kJ} \mathrm{~mol}^{-1}$ coupled with a modest $\mathrm{CO}_{2}$ adsorption capacity of $2.2 \mathrm{mmol} \mathrm{g}^{-1}$. Both network PIMs displayed high theoretical ideal adsorbed solution theory $\mathrm{CO}_{2} /$ $\mathrm{N}_{2}$ selectivities ( 51 and 94 at $273 \mathrm{~K}$ vs 34 and 84 at $298 \mathrm{~K}$ for MP1 and MP2, respectively). The high selectivities of MP1 and MP2 were confirmed by experimental column breakthrough experiments with $\mathrm{CO}_{2} / \mathrm{N}_{2}$ selectivity values of 23 and 45 , respectively. Besides the promising $\mathrm{CO}_{2}$ capture and $\mathrm{CO}_{2} / \mathrm{N}_{2}$ selectivity properties, MP1 also demonstrated high sorption capacity for toxic volatile organic vapors. At $298 \mathrm{~K}$ and a relative pressure of 0.95 , benzene and toluene sorption uptakes reached 765 and $1041 \mathrm{mg} \mathrm{g}^{-1}$, respectively. Moreover, MP1 also demonstrated some potential for adsorptive separation of xylene isomers with adsorptive selectivity of 1.75 for $m$-xylene/o-xylene.

\section{INTRODUCTION}

Organic network polymers often exhibit excellent chemical stability, large microporosity and tunable pore sizes, synthetic versatility, and diversity in functionality, leading to great potential in a variety of applications such as carbon capture and sequestration, ${ }^{1-4}$ catalytic reactions, ${ }^{5-8}$ emerging toxic organic vapor removal, and others. ${ }^{9,10}$ Porous organic polymers (POPs) can be classified into several categories, such as hyper-cross-linked polymers (HCPs), ${ }^{11,12}$ covalent organic frameworks (COFs), ${ }^{13-15}$ porous aromatic frameworks (PAFs), ${ }^{16}$ conjugated microporous polymers $(\mathrm{CMPs})^{17-21}$ and polymers of intrinsic microporosity (PIMs). ${ }^{22-28}$ For efficient $\mathrm{CO}_{2}$ capture, both high $\mathrm{CO}_{2}$ capacity and $\mathrm{CO}_{2} / \mathrm{N}_{2}$ selectivity are required. ${ }^{3,11,12,29,30} \mathrm{CO}_{2}$ capacity can be boosted by introducing polar groups to enhance the interaction between the polymer and $\mathrm{CO}_{2}$ molecules, especially by introducing the nitrogen functionality; $\mathrm{CO}_{2} / \mathrm{N}_{2}$ selectivity can be improved by fine tuning the pore size of the POPs. ${ }^{10,31-35}$

PIMs can be divided into soluble linear ladder polymers and porous cross-linked network materials. ${ }^{26,36,37}$ The prototype linear ladder PIM-1, first reported by Budd and McKeown in 2004, was formed by polycondensation of 3,3,3'3'-tetramethyl spirobisindane-5,5,6,6'-tetraol and tetrafluorophthalonitrile using $\mathrm{K}_{2} \mathrm{CO}_{3}$ as the catalyst. ${ }^{22}$ A large number of soluble ladder PIMs were developed thereafter for membrane-based gas separation, catalyst, sensor applications, and so

Received: September 27, 2018

Accepted: November 9, 2018

Published: November 27, 2018 
Scheme 1. Synthetic Procedure of Tetraphenylethylene-Based Network PIM (MP1) and Its Carboxylated Polymer (MP2)

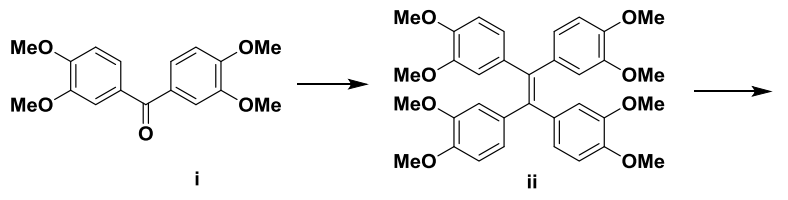<smiles>Oc1cccc(C(=C(c2ccc(O)c(O)c2)c2ccc(O)c(O)c2)c2ccc(O)c(O)c2)c1</smiles>
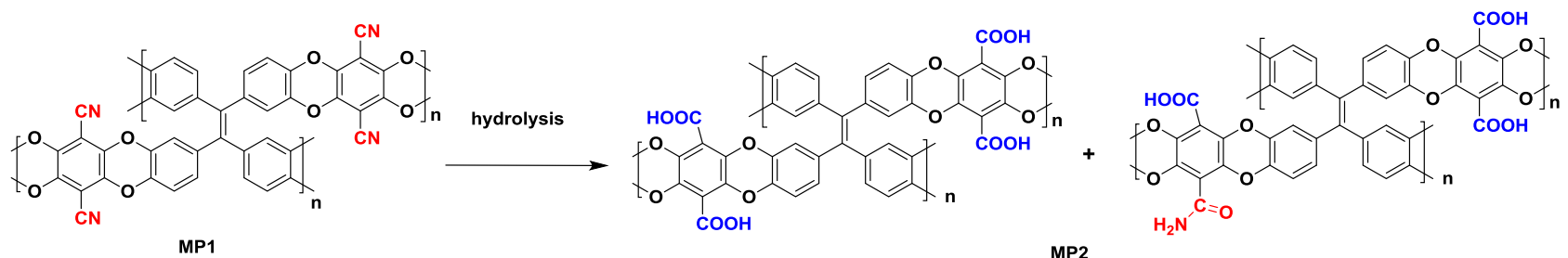

forth. $^{23,38-42}$ The first network PIMs, phthalocyanine-based nanoporous network polymers, were reported by Mckeown's group in 2002 and exhibited a surface area of around 450-900 $\mathrm{m}^{2} \mathrm{~g}^{-1} \cdot{ }^{37}$ Later, several network PIMs were developed with good $\mathrm{H}_{2}$ storage properties and catalytic activity. ${ }^{6,26-28,43-47}$

Tetraphenylethylene is a $D_{2 h}$ molecule widely used as an aggregation-induced emission element because of the inefficient packing in the resulting polymers caused by the twisted structure of the tetraphenylethylene building block. ${ }^{48,49}$ This site of contortion has also been applied as the building block of POPs and COFs to achieve materials with large porosity, unique electronic properties, and so forth. ${ }^{48,50-56}$ In addition, tetraphenylethylene has been used as a soluble ladder PIM in membrane-based gas separation applications. ${ }^{57}$ Endowed by the unique properties of this "kinked" structure, we adopted this site of contortion to design a new network PIM (MP1) and a $\mathrm{COOH}$-functionalized derivative network PIM (MP2 made by hydrolysis of MP1). Here, we report the potential of the pristine network PIM and $\mathrm{COOH}$-functionalized PIM for potential $\mathrm{CO}_{2}$ capture and some toxic volatile organic vapor removal. The general synthetic procedures of intermediates, monomer, MP1, and MP2 are shown in Scheme 1. The detailed syntheses and characterizations of the intermediates and network PIMs are listed in the Supporting Information. Their chemical structure identification, thermal and chemical properties, porosity and pore size distributions, gas adsorption and separation, as well as organic toxic vapor sorption properties are reported.

\section{RESULTS AND DISCUSSION}

\subsection{Synthesis and Characterization of MP1 and MP2}

Networks. The synthesis of the intermediate 1,1,2,2-tetrakis(3,4-dimethoxyphenyl)ethane (ii) followed a previously reported procedure, and a good yield was obtained. ${ }^{59}$ Compound (ii) was further reacted with $\mathrm{BBr}_{3}$ in dichloromethane solution to remove all methyl groups and form intermediate (iii). Monomer (iii) octa-hydroxyltetraphenylethylene has a functionality $f=4$ when reacted with $2,3,5,6$ tetrafluoroterephthalonitrile $(f=2)$ with an equal functional group ratio using the conventional PIM formation method by heating the mixture to $120{ }^{\circ} \mathrm{C}$ for $6 \mathrm{~h}$. The resulting tetraphenylethylene-based network PIM (MP1) was obtained in a very good yield. After drying, the MP1 was ball-milled to a fine powder and further hydrolyzed in a concentrated ethanol/ $\mathrm{KOH} /$ water solution for $48 \mathrm{~h}$ with 100 times $\mathrm{KOH}$ excess. A hydrolyzed network PIM with $\mathrm{COOH}$ functionalization was obtained and denoted as MP2. This hydrolysis method has been widely used and studied for the linear soluble carboxylic group-functionalized PIM-1. ${ }^{60}$ Elementary analysis results showed that the $\mathrm{N}$ content was $1.87 \%$, which indicated that the MP1 was not fully converted ( $\sim 75 \%$ of $\mathrm{CN}$ hydrolyzed to $\mathrm{COOH}$ and $25 \%$ converted to $\mathrm{CONH}_{2}$ ) because the insoluble MP1 network impeded the accessibility of the catalyst and the base. Similar to the hydrolysis of PIM-1, some byproducts such as acetic amide can be formed at the same time. ${ }^{60-63}$ Their structures were analyzed and identified by solid-state ${ }^{13} \mathrm{C}$ crosspolarization magic angle spinning (CP-MAS) nuclear magnetic resonance (NMR) and Fourier transform infrared spectroscopy (FT-IR), as shown in Figures 1 and 2. MP1 and MP2 were

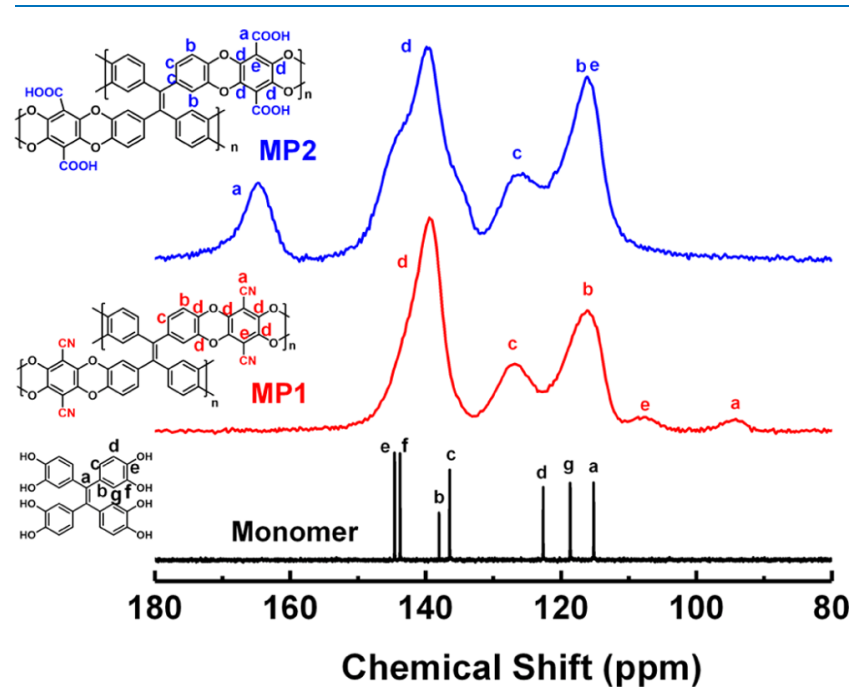

Figure 1. ${ }^{13} \mathrm{C}$ NMR of the monomer (iii) and ${ }^{13} \mathrm{CP}$-MAS spectra of MP1 and MP2. The NMR signals were obtained using MAS with a frequency of $14 \mathrm{kHz}$.

completely insoluble in a conventional organic solvent such as $N, N$-dimethylformamide, $N$-methylpyrrolidone, chloroform, methanol, water, and others, indicating that these polymers are highly cross-linked networks.

MP1 and MP2 displayed five types of broad carbon peaks as shown in Figure 1. The chemical shift of CN carbon in MP1 was located at $94 \mathrm{ppm}$ (Figure 1). After hydrolysis under the basic condition, the majority of $\mathrm{CN}$ converted to $\mathrm{COOH}$ groups, which exhibited a chemical shift of the carbon toward a lower field of $164.7 \mathrm{ppm}$ in MP2. Moreover, the stronger electronic-withdrawing effect of the $\mathrm{COOH}$ group moved the chemical shift of nearby carbon e from $108 \mathrm{ppm}$ of MP1 to the 


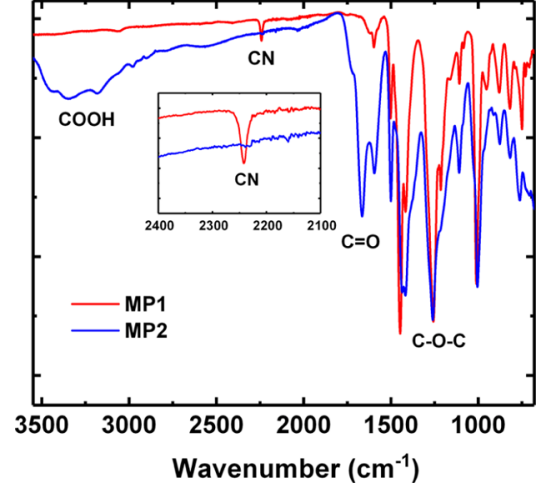

Figure 2. FT-IR spectra of MP1 and MP2; the disappearance of the $\mathrm{CN}$ bond at $2240 \mathrm{~cm}^{-1}$ in MP2 is highlighted.

same as carbon b of $113 \mathrm{ppm}$ and immerged in the broad peak of carbon $b$.

The hydrolysis of $-\mathrm{CN}$ to $-\mathrm{COOH}$ groups was also confirmed by their FT-IR spectra, as shown in Figure 2. The $\mathrm{CN}$ signal at $2240 \mathrm{~cm}^{-1}$ disappeared completely indicating full hydrolysis of the $\mathrm{CN}$ group (figure insert in Figure 2). At the same time, strong bonds emerged in the signals of 2900-3600 $\mathrm{cm}^{-1}$ and $1660-1750 \mathrm{~cm}^{-1}$, suggesting the formation of $\mathrm{COOH}$ groups.

The two network PIMs demonstrated high thermal stabilities; their thermal gravimetric analysis (TGA) spectra under a $\mathrm{N}_{2}$ atmosphere are shown in Figure 3. MP1 and MP2

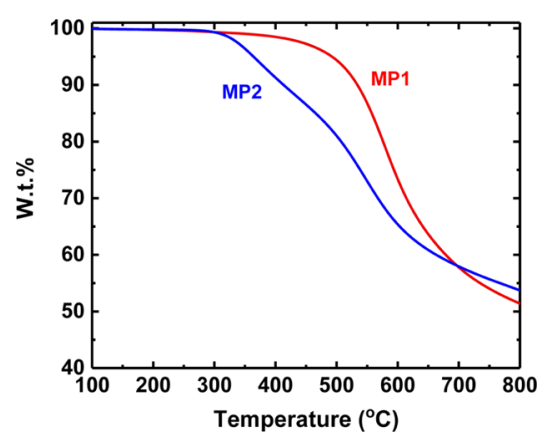

Figure 3. TGA of MP1 and MP2. The powder was heated at a ramp rate of $3{ }^{\circ} \mathrm{C} / \mathrm{min}$ from room temperature to $800{ }^{\circ} \mathrm{C}$ under a $\mathrm{N}_{2}$ atmosphere.

exhibited onset decomposition temperatures of 450 and 320 ${ }^{\circ} \mathrm{C}$, respectively. After hydrolysis of $\mathrm{CN}$ to $\mathrm{COOH}$, a weight loss of about $10 \%$ was observed from 300 to $450{ }^{\circ} \mathrm{C}$, which might be caused by the decomposition related to the $\mathrm{COOH}$ group.

Similar to many other PIMs, MP1 and MP2 demonstrated completely amorphous structures, as indicated by their wideangle X-ray scattering results illustrated in Figure 4. After hydrolysis, the main halo increased from $2 \theta$ of $12^{\circ}$ of MP1 to $20.7^{\circ}$ of MP2, corresponding to a decrease in the average chain $d$-spacing from 7.38 to $4.29 \AA$. This result clearly suggests that the carboxylation in MP2 yielded much tighter average chain packing than in MP1. Moreover, the shape of the spectra changed from a bimodal distribution in MP1 to an almost single-peak distribution in MP2, indicating a more uniform distribution of micropores in the hydrolyzed MP2 than MP1.

The Brunauer-Emmett-Teller (BET) surface areas of the tetraphenylethylene-based network PIMs were analyzed by

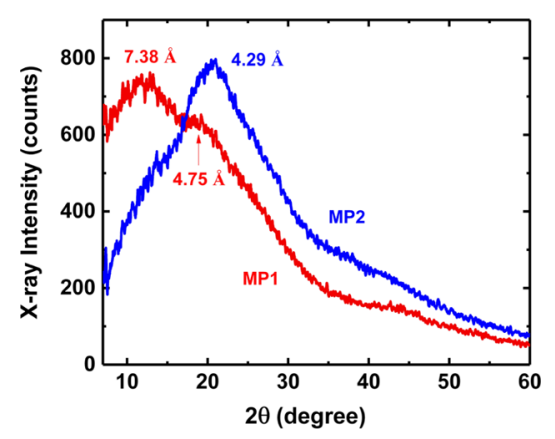

Figure 4. Wide-angle X-ray scattering spectra of MP1 and MP2 powders.

nitrogen adsorption isotherms measured at $77 \mathrm{~K}$ (Figure 5a). MP1 demonstrated a large microporosity as indicated by high adsorption values at low relative pressure $\left(p / p_{0}<0.1\right)$ MP1 displayed a BET surface area of $1020 \mathrm{~m}^{2} \mathrm{~g}^{-1}$, which is in the range of most conventional POPs such as CMPs (522-1043 $\left.\mathrm{m}^{2} \mathrm{~g}^{-1}\right),{ }^{17,64}$ PIMs $\left(618-1760 \mathrm{~m}^{2} \mathrm{~g}^{-1}\right),{ }^{45}$ ALPs $(412-1235$ $\left.\mathrm{m}^{2} \mathrm{~g}^{-1}\right),{ }^{35,65}$ and azo-COPs $\left(435-1340 \mathrm{~m}^{2} \mathrm{~g}^{-1}\right) .{ }^{66}$ The hydrolysis of $\mathrm{CN}$ in $\mathrm{MP} 1$ to $\mathrm{COOH}$ in $\mathrm{MP} 2$ resulted in a significant decrease in the BET surface area from 1020 to 150 $\mathrm{m}^{2} \mathrm{~g}^{-1}$. Their pore size distribution, derived from nonlocal density functional theory (NLDFT) analysis of their $\mathrm{N}_{2}$ adsorption isotherms, clearly showed a broader distribution in MP1 with ultramicropores of 5-7 $\AA$ and a large fraction of micropores between 10 and $20 \AA$ (Figure 5b). In MP2, the majority of pores fall between 8 and $14 \AA$; no ultramicropores of less than $7 \AA$ could be detected in MP2 by $\mathrm{N}_{2}$ adsorption; this could indicate the creation of smaller pores of less than 5 $\AA$. Overall, this qualitative analysis is consistent with the aforementioned hydrolysis of $\mathrm{CN}$ to $\mathrm{COOH}$ that resulted in smaller pores and more uniform chain packing, as supported by the wide-angle X-ray diffraction (WAXD) results with an average chain spacing of $4.29 \AA$.

2.2. Gas Storage and Separation. To evaluate the gas sorption and separation capacity, the adsorptions of $\mathrm{N}_{2}, \mathrm{CH}_{4}$, and $\mathrm{CO}_{2}$ for MP1 and MP2 at 273 and $298 \mathrm{~K}$ are shown in Figure 6. The network polymers exhibited a high gas adsorption capacity. For example, the $\mathrm{CO}_{2}$ adsorption capacity of MP1 was $4.2 \mathrm{mmol} \mathrm{g}^{-1}$ at $273 \mathrm{~K}$ at 1 bar pressure. This value is in the range of the highest adsorption values among all previously reported network polymers (Table 1), higher than PAF-1 $\left(2.05 \mathrm{mmol} \mathrm{g}^{-1}\right),{ }^{16}$ COFs $\left(1.02-2.23 \mathrm{mmol} \mathrm{g}^{-1}\right){ }^{67}$ TCMPs $\left(1.25-2.8 \mathrm{mmol} \mathrm{g}^{-1}\right),{ }^{68}$ and POM-IM $(1.2-3.3 \mathrm{mmol}$ $\left.\mathrm{g}^{-1}\right)^{69}$ and comparable to network polymers with $\mathrm{N}$-functionalized groups such as imidazole- and azo- and Tröger's basebased POPs [BILPs $\left(2.5-5.2 \mathrm{mmol} \mathrm{g}^{-1}\right),{ }^{33,34,70}$ ALPs (3.24$\left.5.36 \mathrm{mmol} \mathrm{g}^{-1}\right),{ }^{31,35}$ and TBs $\left.\left(4.05-5.19 \mathrm{mmol} \mathrm{g}^{-1}\right)\right] .^{31,71}$ The high $\mathrm{CO}_{2}$ sorption capacity may be attributed to the large surface area and high concentration of the polar $\mathrm{CN}$ groups, which favor the affinity of quadrupole $\mathrm{CO}_{2}$ molecules by dipolar-dipolar interaction. After hydrolysis, the MP2 polymer exhibited a reduced $\mathrm{CO}_{2}$ adsorption capacity of $2.2 \mathrm{mmol} \mathrm{g}^{-1}$ at $273 \mathrm{~K}$ and $1.50 \mathrm{mmol} \mathrm{g}^{-1}$ at $298 \mathrm{~K}$. However, this value is also high among most of the $\mathrm{COOH}$-functionalized network polymers such as CMP1-COOH $\left(1.60 \mathrm{mmol} \mathrm{g}^{-1}\right),{ }^{64} \mathrm{PAF}-26$ COOH $\left(2.32 \mathrm{mmol} \mathrm{g}^{-1}\right){ }^{72}$ PAF-33-COOH $(1.94 \mathrm{mmol}$ $\left.\mathrm{g}^{-1}\right),^{73}$ and $[\mathrm{HOOC}] 25 \%-\mathrm{H}_{2} \mathrm{P}-\mathrm{COF}\left(2.18 \mathrm{mmol} \mathrm{g}{ }^{-1}\right){ }^{74}$ indicating that the $\mathrm{COOH}$-functionalized MP2 PIM is a very promising $\mathrm{CO}_{2}$ adsorbent. 

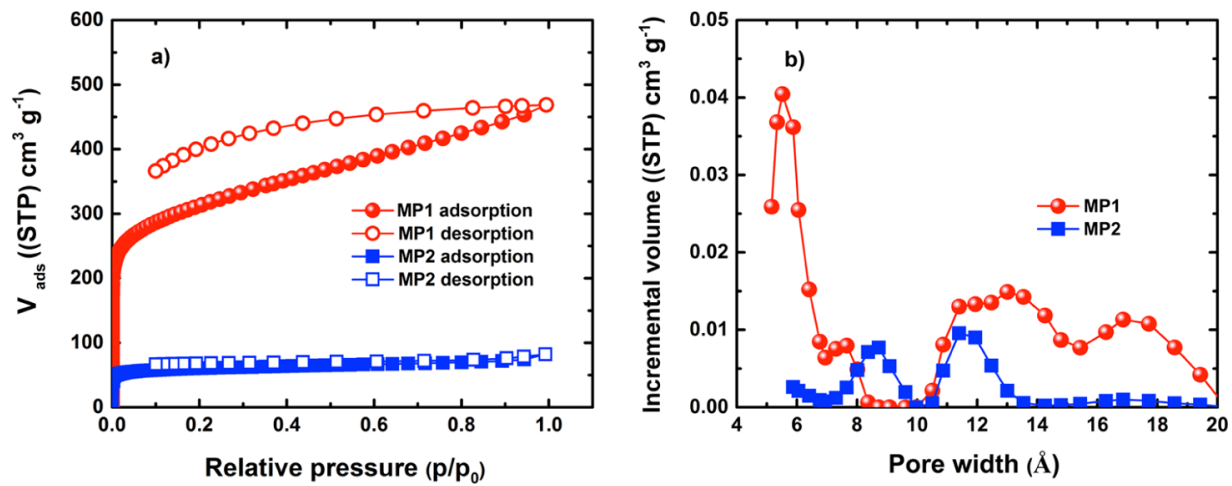

Figure 5. (a) $\mathrm{N}_{2}$ adsorption/desorption isotherms of MP1 and MP2 (left) at $77 \mathrm{~K}$. (b) Pore size distribution of MP1 and MP2 derived by NLDFT analysis of their $\mathrm{N}_{2}$ adsorption isotherms.
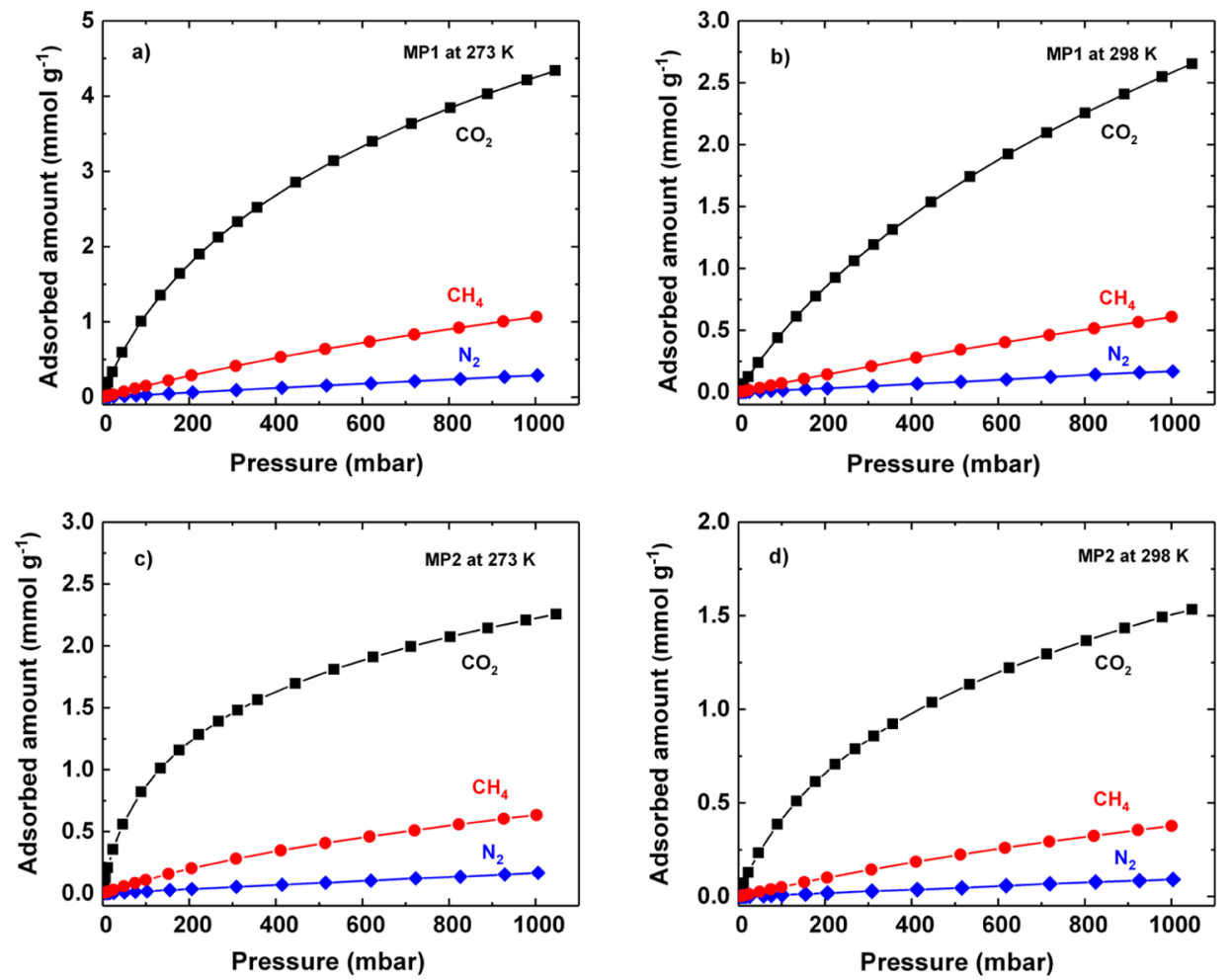

Figure 6. (a) $\mathrm{N}_{2}, \mathrm{CH}_{4}$, and $\mathrm{CO}_{2}$ adsorption isotherms of MP1 at $273 \mathrm{~K}$. (b) $\mathrm{N}_{2}, \mathrm{CH}_{4}$, and $\mathrm{CO}_{2}$ adsorption isotherms of $\mathrm{MP1}$ at $298 \mathrm{~K}$. (c) $\mathrm{N}_{2}$, $\mathrm{CH}_{4}$, and $\mathrm{CO}_{2}$ adsorption isotherms of $\mathrm{MP2}$ at $273 \mathrm{~K}$. (d) $\mathrm{N}_{2}, \mathrm{CH}_{4}$, and $\mathrm{CO}_{2}$ adsorption isotherms of MP2 at $298 \mathrm{~K}$.

Table 1. BET Surface Area, $\mathrm{CO}_{2}$ Sorption Capacity, and Heat of Sorption of MP1 and MP2

\begin{tabular}{|c|c|c|c|c|c|c|}
\hline & \multirow[b]{2}{*}{$S_{\mathrm{BET}}\left(\mathrm{m}^{2} / \mathrm{g}\right)$} & \multicolumn{2}{|c|}{$\begin{array}{c}\mathrm{CO}_{2} \text { sorption } \\
\text { capacity, } \\
0.15 \mathrm{bar}^{-1} \\
\mathrm{mmol} \mathrm{g}^{-1}\end{array}$} & \multicolumn{2}{|c|}{$\begin{array}{l}\mathrm{CO}_{2} \text { sorption } \\
\text { capacity, } 1 \text { bar, } \\
\text { mmol g } \mathrm{g}^{-1}\end{array}$} & \multirow[b]{2}{*}{$Q_{s t}\left(\mathrm{~kJ} \mathrm{~mol}^{-1}\right)$} \\
\hline & & $273 \mathrm{~K}$ & $298 \mathrm{~K}$ & $273 \mathrm{~K}$ & $298 \mathrm{~K}$ & \\
\hline MP1 & 1020 & 1.45 & 0.67 & 4.24 & 2.58 & 29.6 \\
\hline MP2 & 190 & 1.06 & 0.55 & 2.22 & 1.50 & 34.2 \\
\hline
\end{tabular}

To determine the $\mathrm{CO}_{2}$ binding affinity of MP1 and MP2, their $\mathrm{CO}_{2}$ isosteric heats of adsorption $\left(Q_{\mathrm{st}}\right)$ were determined at infinite dilution loading and were calculated from the $\mathrm{CO}_{2}$ adsorption data collected at 273 and $298 \mathrm{~K}$ using the Clausius-Clapeyron equation (Figure $\mathrm{S} 1$ ). The $Q_{\mathrm{st}}$ value of $\mathrm{CO}_{2}$ at a very dilute concentration for MP1 and MP2 is 29.6 and $34.2 \mathrm{~kJ} \mathrm{~mol}^{-1}$, respectively. The $Q_{\mathrm{st}}$ value of MP1 is relatively high among those of other POPs, which are in the range of $20-26 \mathrm{~kJ} \mathrm{~mol}^{-1}$ (e.g., HCP: $20.0-24.0 \mathrm{~kJ} \mathrm{~mol}^{-1}$ and MCTFs: $20.5-26.3 \mathrm{~kJ} \mathrm{~mol}^{-1}$ ) and comparable to those of imidazole-based POPs $\left(26-34 \mathrm{~kJ} \mathrm{~mol}^{-1}\right){ }^{30}$ After hydrolysis, MP2 showed a much higher isosteric heat of adsorption $\left(Q_{s t}\right)$ than MP1 (34.2 vs $\left.29.6 \mathrm{~kJ} \mathrm{~mol}^{-1}\right)$; this is a high value among all functionalized POPs, indicating a strong affinity for $\mathrm{CO}_{2}$ to MP2. This result has previously been reported by Dawson et al. where the highest $\mathrm{CO}_{2} Q_{\mathrm{st}}$ values were obtained for $-\mathrm{COOH}$-derived networks in a series of functionalized polar CMPs. $^{64}$

The $\mathrm{CO}_{2} / \mathrm{N}_{2}$ and $\mathrm{CO}_{2} / \mathrm{CH}_{4}$ selectivities of MP1 and MP2 at 273 and $298 \mathrm{~K}$ were obtained by two methods: First, their selectivities were calculated using an ideal adsorbed solution theory (IAST), shown in Figure 7, at an equilibrium partial pressure for $\mathrm{CO}_{2} / \mathrm{N}_{2}$ of $0.15 / 0.85$ bar in the bulk phase and 0.5 bar/ 0.5 bar for $\mathrm{CO}_{2} / \mathrm{CH}_{4}$. Second, the selectivity for $\mathrm{CO}_{2} /$ 

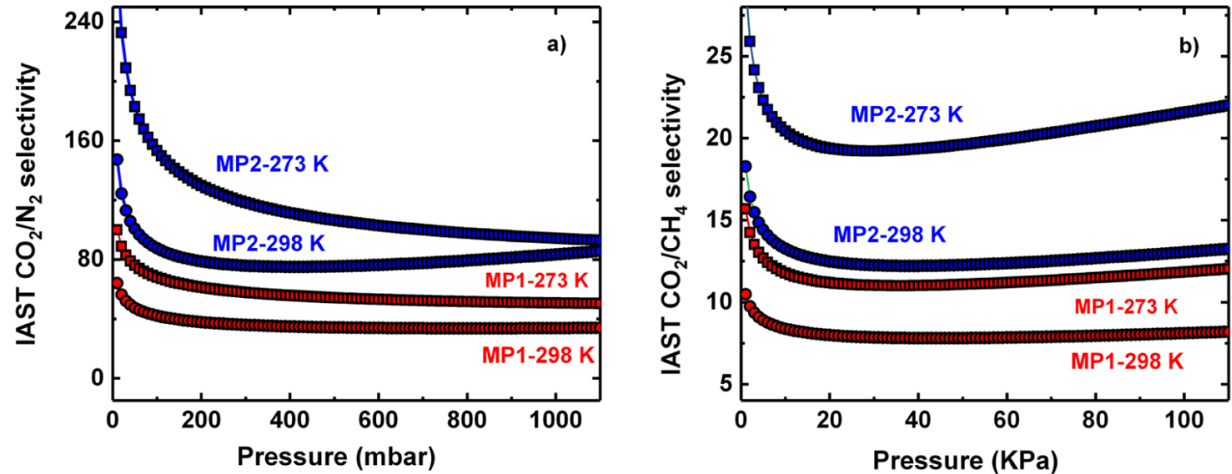

Figure 7. (a) IAST selectivity of MP1 and MP2 for $\mathrm{CO}_{2} / \mathrm{N}_{2}$ at different pressures and temperatures. (b) IAST selectivity of MP1 and MP2 for $\mathrm{CO}_{2} / \mathrm{CH}_{4}$ at different pressures and temperatures. The ratio of $\mathrm{CO}_{2} / \mathrm{N}_{2}$ and $\mathrm{CO}_{2} / \mathrm{CH}_{4}$ was $15 / 85$ and 50/50, and the temperature was 273 and $298 \mathrm{~K}$, respectively.

$\mathrm{N}_{2}$ was also carried out using a breakthrough experiment at $298 \mathrm{~K}$; detailed experimental procedures are shown in the Supporting Information (Figure S4), and the results are summarized in Table 2 . From Table 2 , the $\mathrm{CO}_{2} / \mathrm{N}_{2}$ selectivity

Table 2. Selectivity of $\mathrm{CO}_{2} / \mathrm{N}_{2}$ and $\mathrm{CO}_{2} / \mathrm{CH}_{4}$ Measured with Different Methods

\begin{tabular}{|c|c|c|c|c|c|}
\hline & \multicolumn{2}{|c|}{$\mathrm{CO}_{2} / \mathrm{N}_{2}(\mathrm{IAST})^{a}$} & \multicolumn{2}{|c|}{$\mathrm{CO}_{2} / \mathrm{CH}_{4}(\mathrm{IAST})^{a}$} & \multirow{2}{*}{$\frac{\mathrm{CO}_{2} / \mathrm{N}_{2}(\mathrm{BT})^{b}}{298 \mathrm{~K}}$} \\
\hline & $273 \mathrm{~K}$ & $298 \mathrm{~K}$ & $273 \mathrm{~K}$ & $298 \mathrm{~K}$ & \\
\hline MP1 & 51 & 34 & 11.9 & 8.1 & 23 \\
\hline MP2 & 94 & 84 & 21.6 & 13.1 & 45 \\
\hline
\end{tabular}

${ }^{a}$ IAST selectivity of MP1 and MP2 calculated for $\mathrm{CO}_{2} / \mathrm{N}_{2}$ and $\mathrm{CO}_{2} /$ $\mathrm{CH}_{4}$ at 273 and $298 \mathrm{~K} .{ }^{b}$ Breakthrough experiment selectivity of MP1 and MP2 at $298 \mathrm{~K}$.

obtained by IAST for MP1 is 51 at $273 \mathrm{~K}$ and 34 at $298 \mathrm{~K}$; these values are in the range of PAF-56 (40), SNW-1 (50), ${ }^{75}$ BILP-10 (57), and BTAP-2 (36-58). Notably, when MP1 was hydrolyzed to MP2, a significant enhancement was observed in $\mathrm{CO}_{2} / \mathrm{N}_{2}$ selectivity to 94 at $273 \mathrm{~K}$ and 84 at $298 \mathrm{~K}$. These values are high relative to all reported $\mathrm{COOH}$-functionalized organic porous materials to date, such as PAF-26-COOH (20), PAF-26-COOK (50), PAF-26-COONa (53), and [HOOC]$\mathrm{H}_{2} \mathrm{P}-\mathrm{COF}(77) .^{30}$ The $\mathrm{CO}_{2} / \mathrm{CH}_{4}$ IAST selectivity of MP1 and MP2 are $11.9-21.6$ at $273 \mathrm{~K}$, respectively. The $\mathrm{CO}_{2} / \mathrm{CH}_{4}$ sorption selectivity of 21.6 is also in the range of the highest $\mathrm{CO}_{2} / \mathrm{CH}_{4}$ solubility selectivity reported to date, higher than the functionalized CMP such as CBZ (13.2) and IN (15). ${ }^{76}$
The selectivity of $\mathrm{CO}_{2} / \mathrm{CH}_{4}$ decreased to 8.1 and 11.3 for MP1 and MP2, respectively, by increasing the temperature from 273 to $298 \mathrm{~K}$.

$\mathrm{CO}_{2} / \mathrm{N}_{2}$ gas separation performance by breakthrough experiments of MP1 and MP2 were conducted using a custom-made set up (see the Supporting Information). At a flow rate of $10 \mathrm{~mL} / \mathrm{min}$ and a $\mathrm{CO}_{2} / \mathrm{N}_{2}$ component ratio of $15 /$ 85 , their breakthrough results at $298 \mathrm{~K}$ are shown in Figure 8.

$\mathrm{N}_{2}$ appears at a shorter time (83 s) after introduction to the column than $\mathrm{CO}_{2}(152 \mathrm{~s})$ in $\mathrm{MP} 1$, yielding a $\mathrm{CO}_{2} / \mathrm{N}_{2}$ selectivity of 23 . The $\mathrm{COOH}$-functionalized MP2 even exhibited a $\mathrm{CO}_{2} / \mathrm{N}_{2}$ selectivity of 45 , which is comparable to the potassium-doped porous carbon KNC-A-K (44). ${ }^{77}$ The loading amount of MP2 was about half of MP1. The lower adsorption amount and higher $\mathrm{CO}_{2} / \mathrm{N}_{2}$ selectivity followed the same qualitative trend as calculated from the IAST results. This result may be attributed to the more uniform pore size distribution of MP2, as discussed from the aforementioned NLDFT analysis and WAXD results.

2.3. Vapor Sorption of MP1 and MP2. Highly toxic volatile organic compounds (VOCs), including benzene and its derivatives, are common air and water pollutants. Physical adsorption using organic porous materials could be a potential method for their capture, and some previous work has been reported for network polyimides and CMPs. ${ }^{10,78-82}$ Besides promising $\mathrm{CO}_{2} / \mathrm{N}_{2}$ separation properties, the above network PIM (MP1) also demonstrated good organic solvent adsorption properties, as shown in Figure 9 and Table 3.
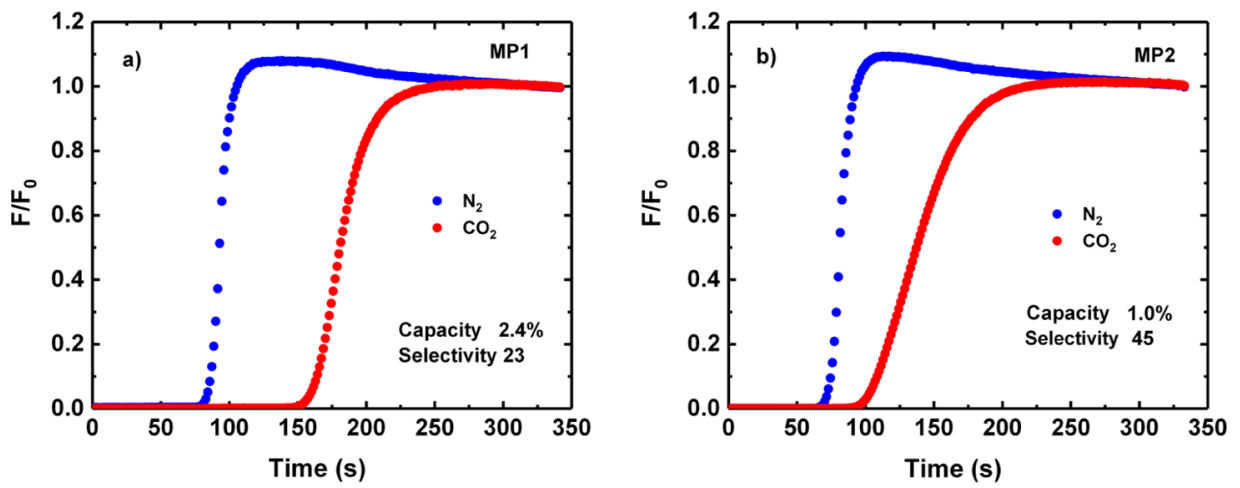

Figure 8. (a) $\mathrm{CO}_{2} / \mathrm{N}_{2}$ breakthrough curves of MP1 and (b) $\mathrm{CO}_{2} / \mathrm{N}_{2}$ breakthrough curves of MP2. The feed of $\mathrm{CO}_{2} / \mathrm{N}_{2}$ was at 1 bar with a component ratio of $15 \mathrm{~mol} \% \mathrm{CO}_{2} / 85 \mathrm{~mol} \% \mathrm{~N}_{2}$ and a flow rate of $10 \mathrm{~mL} / \mathrm{min}$ at $298 \mathrm{~K}$. 

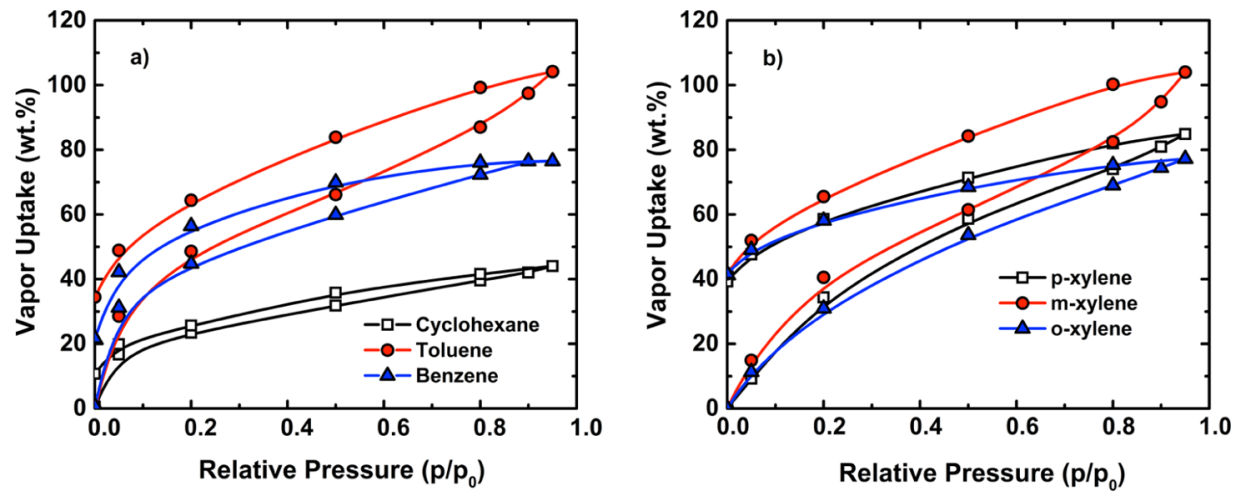

Figure 9. (a) Cyclohexane, benzene, and toluene adsorption/desorption isotherms of MP1. (b) $o$-Xylene, $p$-xylene, and $m$-xylene sorption isotherms of MP1.

Table 3. Vapor Sorption Capacity of the Network PIM-MP1

$\begin{array}{lcccccc}\text { polymer } & \text { cyclohexane } & \text { benzene } & \text { toluene } & m \text {-xylene } & p \text {-xylene } & o \text {-xylene } \\ \mathrm{MP}^{a}{ }^{a} & 440 & 765 & 1041 & 1042 & 849 & 772 \\ S_{\mathrm{X}} / S_{\text {cyclo }}{ }^{b} & & 1.74 & 2.37 & 2.37 & 1.93 & 1.75\end{array}$

${ }^{a_{T}}$ The sorption data were obtained at a relative pressure $p / p_{0}$ of 0.95 ; scale: $\mathrm{mg} \mathrm{g}^{-1}$. ${ }^{b}$ The sorption selectivity of the vapors as compared to cyclohexane.

VOC adsorption in MP1 reached as much as $765 \mathrm{mg} \mathrm{g}^{-1}$ $\left(9.8 \mathrm{mmol} \mathrm{g}^{-1}\right)$ for benzene and $1041 \mathrm{mg} \mathrm{g}^{-1}\left(11.3 \mathrm{mmol} \mathrm{g}^{-1}\right)$ for toluene, which are very high values among POPs, such as PAF-11 (874 $\left.\mathrm{mg} \mathrm{g}^{-1}\right),{ }^{83}$ NPIs $\left(728-1049 \mathrm{mg} \mathrm{g}^{-1}\right),{ }^{84}$ and BoCMPs (590-950 $\left.\mathrm{mg} \mathrm{g}^{-1}\right) .{ }^{82}$ Meanwhile, MP1 also showed potential for adsorptive separation of xylene isomers, in which the absorption amount followed the sequence of $m$-xylene $>p$ xylene $>o$-xylene, where the sorption capacity for $m$-xylene was 1.35 times higher than $o$-xylene (Table 3 ).

\section{CONCLUSIONS}

Here, we report a novel tetraphenylethylene-based network PIM (MP1) and its corresponding COOH-based network PIM (MP2). MP1 exhibited a high surface area of $1020 \mathrm{~m}^{2} \mathrm{~g}^{-1}$ and a $\mathrm{CO}_{2}$ adsorption capacity of $4.2 \mathrm{mmol} \mathrm{g}^{-1}$ at 1 bar and $273 \mathrm{~K}$. The high density of the polar $\mathrm{CN}$ groups displayed strong dipolar interactions with the quadrupole $\mathrm{CO}_{2}$ molecules. The $\mathrm{CO}_{2} / \mathrm{N}_{2}$ selectivity of MP1 based on IAST was 51 at $273 \mathrm{~K}$ and 34 at $298 \mathrm{~K}$. Notably, the $\mathrm{COOH}$-based MP2 exhibited lower BET surface area of $150 \mathrm{~m}^{2} \mathrm{~g}^{-1}$ combined with much higher selectivity for $\mathrm{CO}_{2} / \mathrm{N}_{2}$ of 94 at $273 \mathrm{~K}$ and 84 at $298 \mathrm{~K}$. Breakthrough results at $298 \mathrm{~K}$ also confirmed that the $\mathrm{COOH}$ functionalized MP2 showed higher $\mathrm{CO}_{2} / \mathrm{N}_{2}$ selectivity of 45 than MP1 with a value of 23. Besides the high gas adsorption and separation performance, MP1 also showed a very high volatile organic vapor adsorption capacity for toluene (1041 $\mathrm{mg} \mathrm{g}^{-1}$ ) and $m$-xylene $\left(1042 \mathrm{mg} \mathrm{g}^{-1}\right)$, which suggests that MP1 may have some potential in environmental applications for capture of VOCs.

\section{EXPERIMENTAL SECTION}

4.1. Materials. Bis(3,4-dimethoxyphenyl)methanone was synthesized according to a previously reported method. ${ }^{58}$ Titanium tetrachloride $\left(\mathrm{TiCl}_{4}\right)$, anhydrous tetrahydrofuran, potassium carbonate $\left(\mathrm{K}_{2} \mathrm{CO}_{3}\right)$, dichloromethane, diethyl ether, methanol, boron tribromide $\left(\mathrm{BBr}_{3}\right), \mathrm{N}, \mathrm{N}$-dimethylacetamide, hydrochloride acid $(\mathrm{HCl})$, potassium hydroxide $(\mathrm{KOH})$, and ethanol were obtained from Sigma-Aldrich and used as received.

4.2. Characterization Methods. Liquid ${ }^{1} \mathrm{H}$ NMR and ${ }^{13} \mathrm{C}$ NMR spectra of the monomer and intermediates were characterized with a Bruker AVANCE-III NMR spectrometer with a frequency of 400 or $500 \mathrm{MHz}$ in $\mathrm{CDCl}_{3}$ or dimethyl sulfoxide- $d_{6}$ with tetramethylsilane as the internal standard. ${ }^{13} \mathrm{C}$ CP-MAS of the network PIMs were performed using a Bruker AVANCE-III $400 \mathrm{MHz}$ NMR instrument with a $3.2 \mathrm{~mm}$ rotor; the rotation speed was kept at $14 \mathrm{k} \mathrm{rpm}$. High-resolution mass spectroscopy of the monomer was conducted on a Thermo LC/MS system with LTQ Orbitrap Velos detectors. Elemental analysis of the intermediates and polymers were performed using a Thermo Flash EA2000 elemental analyzer. FT-IR spectra were acquired using a Thermo Nicolet iS10 infrared micro-spectrometer. TGA of the network PIMs was carried out using a TGA Q5000 analyzer. The BET surface area of the polymers was measured by $\mathrm{N}_{2}$ adsorption at $77 \mathrm{~K}$ (Micrometrics ASAP 2020 with micropore option); their pore size distributions were determined using the NLDFT model, with software from Micrometrics. $\mathrm{N}_{2}, \mathrm{CH}_{4}$, and $\mathrm{CO}_{2}$ adsorption isotherms were performed on a Micrometrics ASAP 2050 instrument at 273 and $298 \mathrm{~K}$ up to 1 bar. Dynamic vapor sorption of benzene, toluene, cyclohexane, and xylene isomers were measured using a TA step isotherm vapor adsorption instrument (VTI-SA) at $25{ }^{\circ} \mathrm{C}$; the relative pressure $\left(p / p_{\text {sat }}\right)$ was gradually increased from 5 to $95 \%$ after sorption equilibrium was reached for each data point. WAXD of the network powder was performed on a Bruker D8 ADVANCE diffractometer with a scanning rate of $0.5^{\circ} / \mathrm{min}$ from $6^{\circ}$ to $70^{\circ}$.

\section{ASSOCIATED CONTENT}

\section{Supporting Information}

The Supporting Information is available free of charge on the ACS Publications website at DOI: 10.1021/acsomega.8b02544.

Syntheses and characterizations of the intermediates, monomer, and MP1 and MP2 networks; isosteric heats 
of adsorption; IAST calculation procedure of MP1 and $\mathrm{MP} 2$ for $\mathrm{CO}_{2} / \mathrm{N}_{2}$ and $\mathrm{CO}_{2} / \mathrm{CH}_{4}$; breakthrough experiments (PDF)

\section{AUTHOR INFORMATION}

\section{Corresponding Author}

*E-mail: ingo.pinnau@kaust.edu.sa.

ORCID $\odot$

Yu Han: 0000-0003-1462-1118

Ingo Pinnau: 0000-0003-3040-9088

Notes

The authors declare no competing financial interest.

\section{ACKNOWLEDGMENTS}

This work was supported by funding from the King Abdullah University of Science and Technology (KAUST).

\section{REFERENCES}

(1) Chu, S. Carbon Capture and Sequestration. Science 2009, 325, 1599.

(2) Rochelle, G. T. Amine Scrubbing for $\mathrm{CO}_{2}$ Capture. Science 2009, 325, 1652-1654.

(3) D’Alessandro, D. M.; Smit, B.; Long, J. R. Carbon Dioxide Capture: Prospects for New Materials. Angew. Chem., Int. Ed. 2010, 49, 6058-6082.

(4) Chung, W.; Roh, K.; Lee, J. H. Design and Evaluation of $\mathrm{CO}_{2}$ Capture Plants for the Steelmaking Industry by Means of Amine Scrubbing and Membrane Separation. Int. J. Greenhouse Gas. Con. 2018, 74, 259-270.

(5) Li, B.; Guan, Z.; Wang, W.; Yang, X.; Hu, J.; Tan, B.; Li, T. Highly Dispersed Pd Catalyst Locked in Knitting Aryl Network Polymers for Suzuki-Miyaura Coupling Reactions of Aryl Chlorides in Aqueous Media. Adv. Mater. 2012, 24, 3390-3395.

(6) Mackintosh, H. J.; Budd, P. M.; McKeown, N. B. Catalysis by Microporous Phthalocyanine and Porphyrin Network Polymers. J. Mater. Chem. 2008, 18, 573-578.

(7) Zhang, Y.; Riduan, S. N. Functional Porous Organic Polymers for Heterogeneous Catalysis. Chem. Soc. Rev. 2012, 41, 2083-2094.

(8) Sun, Q.; Dai, Z.; Meng, X.; Xiao, F.-S. Porous Polymer Catalysts with Hierarchical Structures. Chem. Soc. Rev. 2015, 44, 6018-6034.

(9) Britt, D.; Tranchemontagne, D.; Yaghi, O. M. Metal-Organic Frameworks with High Capacity and Selectivity for Harmful Gases. Proc. Natl. Acad. Sci. U.S.A. 2008, 105, 11623-11627.

(10) Li, G.; Wang, Z. Microporous Polyimides with Uniform Pores for Adsorption and Separation of $\mathrm{CO}_{2}$ Gas and Organic Vapors. Macromolecules 2013, 46, 3058-3066.

(11) Tan, L.; Tan, B. Hypercrosslinked Porous Polymer Materials: Design, Synthesis, and Applications. Chem. Soc. Rev. 2017, 46, 3481.

(12) Das, S.; Heasman, P.; Ben, T.; Qiu, S. Porous Organic Materials: Strategic Design and Structure-Function Correlation. Chem. Rev. 2017, 117, 1515-1563.

(13) Cote, A. P.; Benin, A. I.; Ockwig, N. W.; O’Keeffe, M.; Matzger, A. J.; Yaghi, O. M. Porous, Crystalline, Covalent Organic Frameworks. Science 2005, 310, 1166-1170.

(14) Fang, Q.; Wang, J.; Gu, S.; Kaspar, R. B.; Zhuang, Z.; Zheng, J.; Guo, H.; Qiu, S.; Yan, Y. 3D Porous Crystalline Polyimide Covalent Organic Frameworks for Drug Delivery. J. Am. Chem. Soc. 2015, 137, 8352-8355.

(15) Ma, H.; Liu, B.; Li, B.; Zhang, L.; Li, Y.-G.; Tan, H.-Q.; Zang, H.-Y.; Zhu, G. Cationic Covalent Organic Frameworks: A Simple Platform of Anionic Exchange for Porosity Tuning and Proton Conduction. J. Am. Chem. Soc. 2016, 138, 5897-5903.

(16) Ben, T.; Ren, H.; Ma, S.; Cao, D.; Lan, J.; Jing, X.; Wang, W.; Xu, J.; Deng, F.; Simmons, J. M.; Qiu, S.; Zhu, G. Targeted Synthesis of a Porous Aromatic Framework with High Stability and Exceptionally High Surface Area. Angew. Chem., Int. Ed. 2009, 48, 9457-9460.
(17) Xu, Y.; Jin, S.; Xu, H.; Nagai, A.; Jiang, D. Conjugated Microporous Polymers: Design, Synthesis and Application. Chem. Soc. Rev. 2013, 42, 8012-8031.

(18) Gu, C.; Huang, N.; Chen, Y.; Qin, L.; Xu, H.; Zhang, S.; Li, F.; Ma, Y.; Jiang, D. $\pi$-Conjugated Microporous Polymer Films: Designed Synthesis, Conducting Properties, and Photoenergy Conversions. Angew. Chem., Int. Ed. 2015, 54, 13594-13598.

(19) Zhang, C.; He, Y.; Mu, P.; Wang, X.; He, Q.; Chen, Y.; Zeng, J.; Wang, F.; Xu, Y.; Jiang, J.-X. Toward High Performance ThiopheneContaining Conjugated Microporous Polymer Anodes for LithiumIon Batteries through Structure Design. Adv. Funct. Mater. 2018, 28, 1705432.

(20) Liao, Y.; Weber, J.; Faul, C. F. J. Conjugated Microporous Polytriphenylamine Networks. Chem. Commun. 2014, 50, 80028005.

(21) Wang, H.; Cheng, Z.; Liao, Y.; Li, J.; Weber, J.; Thomas, A.; Faul, C. F. J. Conjugated Microporous Polycarbazole Networks as Precursors for Nitrogen-Enriched Microporous Carbons for $\mathrm{CO}_{2}$ Storage and Electrochemical Capacitors. Chem. Mater. 2017, 29, 4885-4893.

(22) Budd, P. M.; Elabas, E. S.; Ghanem, B. S.; Makhseed, S.; McKeown, N. B.; Msayib, K. J.; Tattershall, C. E.; Wang, D. SolutionProcessed, Organophilic Membrane Derived from a Polymer of Intrinsic Microporosity. Adv. Mater. 2004, 16, 456-459.

(23) Mckeown, N. B.; Budd, P. M. Polymers of Intrinsic Microporosity (PIMs): Organic Materials for Membrane Separations, Heterogeneous Catalysis and Hydrogen Storage. Chem. Soc. Rev. 2006, 35, 675-683.

(24) Carta, M.; Malpass-Evans, R.; Croad, M.; Rogan, Y.; Jansen, J. C.; Bernardo, P.; Bazzarelli, F.; McKeown, N. B. An Efficient Polymer Molecular Sieve for Membrane Gas Separations. Science 2013, 339, 303-307.

(25) Ghanem, B. S.; Swaidan, R.; Ma, X.; Litwiller, E.; Pinnau, I. Energy-Efficient Hydrogen Separation by AB-Type Ladder-Polymer Molecular Sieves. Adv. Mater. 2014, 26, 6696-6700.

(26) McKeown, N. B.; Hanif, S.; Msayib, K.; Tattershall, C. E.; Budd, P. M. Porphyrin-Based Nanoporous Network Polymers. Chem. Commun. 2002, 2782-2783.

(27) McKeown, N. B.; Ghanem, B.; Msayib, K. J.; Budd, P. M.; Tattershall, C. E.; Mahmood, K.; Tan, S.; Book, D.; Langmi, H. W.; Walton, A. Towards Polymer-Based Hydrogen Storage Materials: Engineering Ultramicroporous Cavities Within Polymers of Intrinsic Microporosity. Angew. Chem., Int. Ed. 2006, 45, 1804-1807.

(28) Ghanem, B. S.; Msayib, K. J.; McKeown, N. B.; Harris, K. D. M.; Pan, Z.; Budd, P. M.; Butler, A.; Selbie, J.; Book, D.; Walton, A. A Triptycene-Based Polymer of Intrinsic Microposity that Displays Enhanced Surface Area and Hydrogen Adsorption. Chem. Commun. 2007, 1, 67-69.

(29) Slater, A. G.; Cooper, A. I. Function-Led Design of New Porous Materials. Science 2015, 348, aaa8075.

(30) Zou, L.; Sun, Y.; Che, S.; Yang, X.; Wang, X.; Bosch, M.; Wang, Q.; Li, H.; Smith, M.; Yuan, S.; Perry, Z.; Zhou, H.-C. Porous Organic Polymers for Post-Combustion Carbon Capture. Adv. Mater. 2017, $29,1700229$.

(31) Zhu, X.; Do-Thanh, C.-L.; Murdock, C. R.; Nelson, K. M.; Tian, C.; Brown, S.; Mahurin, S. M.; Jenkins, D. M.; Hu, J.; Zhao, B.; Liu, H.; Dai, S. Efficient $\mathrm{CO}_{2}$ Capture by a $3 \mathrm{D}$ Porous Polymer Derived from Tröger's Base. ACS Macro Lett. 2013, 2, 660-663.

(32) Rabbani, M. G.; El-Kaderi, H. M. Template-Free Synthesis of a Highly Porous Benzimidazole-Linked Polymer for $\mathrm{CO}_{2}$ Capture and $\mathrm{H}_{2}$ Storage. Chem. Mater. 2011, 23, 1650-1653.

(33) Rabbani, M. G.; El-Kaderi, H. M. Synthesis and Characterization of Porous Benzimidazole-Linked Polymers and Their Performance in Small Gas Storage and Selective Uptake. Chem. Mater. 2012, 24, 1511-1517.

(34) Rabbani, M. G.; Reich, T. E.; Kassab, R. M.; Jackson, K. T.; ElKaderi, H. M. High $\mathrm{CO}_{2}$ Uptake and Selectivity by TriptyceneDerived Benzimidazole-Linked Polymers. Chem. Commun. 2012, 48, $1141-1143$ 
(35) Arab, P.; Rabbani, M. G.; Sekizkardes, A. K.; İslamoğlu, T.; ElKaderi, H. M. Copper(I)-Catalyzed Synthesis of Nanoporous AzoLinked Polymers: Impact of Textural Properties on Gas Storage and Selective Carbon Dioxide Capture. Chem. Mater. 2014, 26, 13851392.

(36) Budd, P. M.; Ghanem, B. S.; Makhseed, S.; McKeown, N. B.; Msayib, K. J.; Tattershall, C. E. Polymers of Intrinsic Microporosity (PIMs): Robust, Solution-Processable, Organic Nanoporous Materials. Chem. Commun. 2004, 230-231.

(37) McKeown, N. B.; Makhseed, S.; Budd, P. M. PhthalocyanineBased Nanoporous Network Polymers. Chem. Commun. 2002, 27802781

(38) Budd, P.; Msayib, K.; Tattershall, C.; Ghanem, B.; Reynolds, K.; McKeown, N.; Fritsch, D. Gas Separation Membranes from Polymers of Intrinsic Microporosity. J. Membr. Sci. 2005, 251, 263269.

(39) McKeown, N. B. Contorted separation. Nat. Mater. 2016, 15, 706-707.

(40) Rose, I.; Bezzu, C. G.; Carta, M.; Comesaña-Gándara, B.; Lasseuguette, E.; Ferrari, M. C.; Bernardo, P.; Clarizia, G.; Fuoco, A.; Jansen, J. C.; Hart, K. E.; Liyana-Arachchi, T. P.; Colina, C. M.; McKeown, N. B. Polymer Ultrapermeability from the Inefficient Packing of 2D Chains. Nat. Mater. 2017, 16, 932-937.

(41) Williams, R.; Burt, L. A.; Esposito, E.; Jansen, J. C.; Tocci, E.; Rizzuto, C.; Lanc, M.; Carta, M.; McKeown, N. B. A highly rigid and gas selective methanopentacene-based polymer of intrinsic microporosity derived from Tröger's base polymerization. J. Mater. Chem. A 2018, 6, 5661-5667.

(42) Wang, Y.; McKeown, N. B.; Msayib, K. J.; Turnbull, G. A.; Samuel, I. D. W. Laser Chemosensor with Rapid Responsivity and Inherent Memory Based on a Polymer of Intrinsic Microporosity. Sensors 2011, 11, 2478-2487.

(43) Budd, P. M.; Ghanem, B.; Msayib, K.; McKeown, N. B.; Tattershall, C. A Nanoporous Network Polymer Derived from Hexaazatrinaphthylene with Potential as an Adsorbent and Catalyst Support. J. Mater. Chem. 2003, 13, 2721-2726.

(44) Maffei, A. V.; Budd, P. M.; McKeown, N. B. Adsorption Studies of a Microporous Phthalocyanine Network Polymer. Langmuir 2006, $22,4225-4229$.

(45) Ghanem, B. S.; Hashem, M.; Harris, K. D. M.; Msayib, K. J.; Xu, M.; Budd, P. M.; Chaukura, N.; Book, D.; Tedds, S.; Walton, A.; McKeown, N. B. Triptycene-Based Polymers of Intrinsic Microporosity: Organic Materials That can be Tailored for Gas Adsorption. Macromolecules 2010, 43, 5287-5294.

(46) Hashem, M.; Grazia Bezzu, C.; Kariuki, B. M.; McKeown, N. B. Enhancing the rigidity of a network polymer of intrinsic microporosity by the combined use of phthalocyanine and triptycene components,. Polym. Chem. 2011, 2, 2190.

(47) Ramimoghadam, D.; Gray, E. M. A.; Webb, C. J. Review of Polymers of Intrinsic Microporosity for Hydrogen Storage Applications. Int. J. Hydrogen Energy 2016, 41, 16944-16965.

(48) Shustova, N. B.; McCarthy, B. D.; Dincă, M. Turn-on Fluorescence in Tetraphenylethylene-Based Metal-Organic Frameworks: An Alternative to Aggregation-Induced Emission. J. Am. Chem. Soc. 2011, 133, 20126-20129.

(49) Mei, J.; Leung, N. L. C.; Kwok, R. T. K.; Lam, J. W. Y.; Tang, B. Z. Aggregation-Induced Emission: Together We Shine, United We Soar! Chem. Rev. 2015, 115, 11718-11940.

(50) Dalapati, S.; Jin, E.; Addicoat, M.; Heine, T.; Jiang, D. Highly Emissive Covalent Organic Frameworks. J. Am. Chem. Soc. 2016, 138, $5797-5800$

(51) Zhou, T.-Y.; Xu, S.-Q.; Wen, Q.; Pang, Z.-F.; Zhao, X. OneStep Construction of Two Different Kinds of Pores in a 2D Covalent Organic Framework. J. Am. Chem. Soc. 2014, 136, 15885-15888.

(52) Pang, Z.-F.; Xu, S.-Q.; Zhou, T.-Y.; Liang, R.-R.; Zhan, T.-G.; Zhao, X. Construction of Covalent Organic Frameworks Bearing Three Different Kinds of Pores through the Heterostructural Mixed Linker Strategy. J. Am. Chem. Soc. 2016, 138, 4710-4713.
(53) Tian, Y.; Xu, S.-Q.; Qian, C.; Pang, Z.-F.; Jiang, G.-F.; Zhao, X. Two-dimensional Dual-Pore Covalent Organic Frameworks Obtained from the Combination of Two D-2h Symmetrical Building Blocks. Chem. Commun. 2016, 52, 11704-11707.

(54) Xiong, J.-B.; Feng, H.-T.; Sun, J.-P.; Xie, W.-Z.; Yang, D.; Liu, M.; Zheng, Y.-S. The Fixed Propeller-Like Conformation of Tetraphenylethylene that Reveals Aggregation-Induced Emission Effect, Chiral Recognition, and Enhanced Chiroptical Property. J. Am. Chem. Soc. 2016, 138, 11469-11472.

(55) Lin, Y.; Jiang, X.; Kim, S. T.; Alahakoon, S. B.; Hou, X.; Zhang, Z.; Thompson, C. M.; Smaldone, R. A.; Ke, C. An Elastic HydrogenBonded Cross-Linked Organic Framework for Effective Iodine Capture in Water. J. Am. Chem. Soc. 2017, 139, 7172-7175.

(56) Qian, C.; Qi, Q.-Y.; Jiang, G.-F.; Cui, F.-Z.; Tian, Y.; Zhao, X. Toward Covalent Organic Frameworks Bearing Three Different Kinds of Pores: The Strategy for Construction and COF-to-COF Transformation via Heterogeneous Linker Exchange. J. Am. Chem. Soc. 2017, 139, 6736-6743.

(57) Ma, X.; Pinnau, I. A novel intrinsically microporous ladder polymer and copolymers derived from 1,1',2,2'-tetrahydroxytetraphenylethylene for membrane-based gas separation. Polym. Chem. 2016, 7, 1244-1248.

(58) Bezzu, C. G.; Carta, M.; Tonkins, A.; Jansen, J. C.; Bernardo, P.; Bazzarelli, F.; McKeown, N. B. A Spirobifluorene-Based Polymer of Intrinsic Microporosity with Improved Performance for Gas Separation. Adv. Mater. 2012, 24, 5930-5933.

(59) Qi, Q.; Liu, Y.; Fang, X.; Zhang, Y.; Chen, P.; Wang, Y.; Yang, B.; Xu, B.; Tian, W.; Zhang, S. X.-A. AIE (AIEE) and Mechanofluorochromic Performances of TPE-methoxylates: Effects of Single Molecular Conformations. RSC Adv. 2013, 3, 7996-8002.

(60) Du, N.; Robertson, G. P.; Song, J.; Pinnau, I.; Guiver, M. D. High-Performance Carboxylated Polymers of Intrinsic Microporosity (PIMs) with Tunable Gas Transport Properties. Macromolecules 2009, 42, 6038-6043.

(61) Satilmis, B.; Budd, P. M. Base-Catalysed Hydrolysis of PIM-1: Amide Versus Carboxylate Formation. RSC Adv. 2014, 4, 5218952198.

(62) Jeon, J. W.; Kim, D.-G.; Sohn, E.-h.; Yoo, Y.; Kim, Y. S.; Kim, B. G.; Lee, J.-C. Highly Carboxylate-Functionalized Polymers of Intrinsic Microporosity for $\mathrm{CO}_{2}$-Selective Polymer Membranes. Macromolecules 2017, 50, 8019-8027.

(63) Santoso, B.; Yanaranop, P.; Kang, H.; Leung, I. K. H.; Jin, J. A Critical Update on the Synthesis of Carboxylated Polymers of Intrinsic Microporosity (C-PIMs). Macromolecules 2017, 50, 30433050.

(64) Dawson, R.; Adams, D. J.; Cooper, A. I. Chemical Tuning of $\mathrm{CO}_{2}$ Sorption in Robust Nanoporous Organic Polymers. Chem. Sci. 2011, 2, 1173-1177.

(65) Arab, P.; Parrish, E.; İslamoğlu, T.; El-Kaderi, H. M. Synthesis and Evaluation of Porous Azo-Linked Polymers for Carbon Dioxide Capture and Separation. J. Mater. Chem. A 2015, 3, 20586-20594.

(66) Patel, H. A.; Je, S. H.; Park, J.; Chen, D. P.; Jung, Y.; Yavuz, C. T.; Coskun, A. Unprecedented High-Temperature $\mathrm{CO}_{2}$ Selectivity in $\mathrm{N}_{2}$-Phobic Nanoporous Covalent Organic Polymers. Nat. Commun. 2013, 4, 1357.

(67) Furukawa, H.; Yaghi, O. M. Storage of Hydrogen, Methane, and Carbon Dioxide in Highly Porous Covalent Organic Frameworks for Clean Energy Applications. J. Am. Chem. Soc. 2009, 131, 88758883.

(68) Ren, S.; Dawson, R.; Laybourn, A.; Jiang, J.-x.; Khimyak, Y.; Adams, D. J.; Cooper, A. I. Functional Conjugated Microporous Polymers: from 1,3,5-Benzene to 1,3,5-Triazine. Polym. Chem. 2012, 3, 928-934.

(69) Wang, J.; Sng, W.; Yi, G.; Zhang, Y. Imidazolium Salt-Modified Porous Hypercrosslinked Polymers for Synergistic $\mathrm{CO}_{2}$ Capture and Conversion. Chem. Commun. 2015, 51, 12076-12079.

(70) Sekizkardes, A. K.; Altarawneh, S.; Kahveci, Z.; İslamoğlu, T.; El-Kaderi, H. M. Highly Selective $\mathrm{CO}_{2}$ Capture by Triazine-Based 
Benzimidazole-Linked Polymers. Macromolecules 2014, 47, 83288334.

(71) Byun, J.; Je, S.-H.; Patel, H. A.; Coskun, A.; Yavuz, C. T. Nanoporous Covalent Organic Polymers Incorporating Tröger's Base Functionalities for Enhanced $\mathrm{CO}_{2}$ Capture. J. Mater. Chem. A 2014, 2, $12507-12512$.

(72) Yan, Y.; Siegwart, D. J. Scalable Synthesis and Derivation of Functional Polyesters Bearing Ene and Epoxide Side Chains. Polym. Chem. 2014, 5, 1362-1371.

(73) Yuan, R.; Ren, H.; Yan, Z.; Wang, A.; Zhu, G. Robust Tri(4ethynylphenyl)amine-Based Porous Aromatic Frameworks for Carbon Dioxide Capture. Polym. Chem. 2014, 5, 2266-2272.

(74) Huang, N.; Chen, X.; Krishna, R.; Jiang, D. Two-Dimensional Covalent Organic Frameworks for Carbon Dioxide Capture through Channel-Wall Functionalization. Angew. Chem., Int. Ed. 2015, 54, 2986-2990.

(75) Gao, X.; Zou, X.; Ma, H.; Meng, S.; Zhu, G. Highly Selective and Permeable Porous Organic Framework Membrane for $\mathrm{CO}_{2}$ Capture. Adv. Mater. 2014, 26, 3644-3648.

(76) Saleh, M.; Lee, H. M.; Kemp, K. C.; Kim, K. S. Highly Stable $\mathrm{CO}_{2} / \mathrm{N}_{2}$ and $\mathrm{CO}_{2} / \mathrm{CH}_{4}$ Selectivity in Hyper-Cross-Linked Heterocyclic Porous Polymers. ACS Appl. Mater. Interfaces 2014, 6, 73257333.

(77) Zhao, L.; Zhai, D.; Liu, B.; Liu, Z.; Xu, C.; Wei, W.; Chen, Y.; Gao, J. Grand Canonical Monte Carlo Simulations for Energy Gases on PIM-1 Polymer and Silicalite-1. Chem. Eng. Sci. 2012, 68, 101107.

(78) Zhang, J.-P.; Chen, X.-M. Exceptional Framework Flexibility and Sorption Behavior of a Multifunctional Porous Cuprous Triazolate Framework. J. Am. Chem. Soc. 2008, 130, 6010-6017.

(79) Ren, H.; Ben, T.; Wang, E.; Jing, X.; Xue, M.; Liu, B.; Cui, Y.; Qiu, S.; Zhu, G. Targeted Synthesis of a 3D Porous Aromatic Framework for Selective Sorption of Benzene. Chem. Commun. 2010, 46, 291-293.

(80) Li, G.; Zhang, B.; Yan, J.; Wang, Z. TetraphenyladamantaneBased Polyaminals for Highly Efficient Captures of $\mathrm{CO}_{2}$ and Organic Vapors. Macromolecules 2014, 47, 6664-6670.

(81) Deng, G.; Wang, Z. Triptycene-Based Microporous Cyanate Resins for Adsorption/Separations of Benzene/Cyclohexane and Carbon Dioxide Gas. ACS Appl. Mater. Interfaces 2017, 9, 4161841627.

(82) Yang, S.-J.; Ding, X.; Han, B.-H. Conjugated Microporous Polymers with Extended $\pi$-Structures for Organic Vapor Adsorption. Macromolecules 2018, 51, 947-953.

(83) Yuan, Y.; Sun, F.; Ren, H.; Jing, X.; Wang, W.; Ma, H.; Zhao, H.; Zhu, G. Targeted Synthesis of a Porous Aromatic Framework with a High Adsorption Capacity for Organic Molecules. J. Mater. Chem. 2011, 21, 13498-13502.

(84) Li, G.; Zhang, B.; Yan, J.; Wang, Z. Microporous Polyimides with Functional Groups for the Adsorption of Carbon Dioxide and Organicr Vapors. J. Mater. Chem. A 2016, 4, 11453-11461. 